\title{
Giant Esophageal Ulcers in a Patient with Human Immunodeficiency Virus
}

\author{
Sung Eun Kim, Seun Ja Park \\ Department of Internal Medicine, Kosin University College of Medicine, Busan, Korea
}

Question: A 56-year-old man presented with retrosternal pain for 2 months. Chest plain film, electrocardiogram, and cardiac-specific markers were normal. Upper endoscopy showed two huge longitudinal ulcerative lesions (about $20 \times 10 \mathrm{~mm}$ and $15 \times 10 \mathrm{~mm}$ in size, respectively) at the middle to distal part of the esophagus (Fig. 1). Other laboratory findings revealed mild pancytopenia and mild derangement of liver function tests. Serum human immunodeficiency virus (HIV) antibody and HIV antigen test were positive. His HIV RNA copies numbered 667,490 copies/mL, and CD4 ${ }^{+}$T-lymphocyte count was 46 cells/ $\mu \mathrm{L}$.

What is the most likely diagnosis?

Answer: Endoscopic biopsy revealed ulcer-related granulation tissue with multiple viral inclusions (Fig. 2A). In addition, positive immunoreaction with cytomegalovi- rus (CMV) was identified in immunohistochemical (IHC) staining (Fig. 2B). Although his CMV immunoglobulin (Ig)M antibody was negative, CMV IgG antibody was positive and CMV real-time PCR showed 229 copies $/ \mathrm{mL}$. Therefore, we diagnosed the patients with giant esophageal ulcers due to CMV infection in acquired immunodeficiency syndrome (AIDS). The patient started treatment with valganciclovir and co-formulation elvitegravir, cobicistat, tenofovir disoproxil fumaratem, and emtricitabine (Stribild ${ }^{\circledR}$ ).

Esophageal ulcer is an important comorbidity in AIDS patients. HIV attacks $\mathrm{CD}^{+} \mathrm{T}$ lymphocytes and causes damage to the gut barrier function. Prospective studies reported that the prevalence of esophageal ulcer is about $30 \sim 40 \%$ in patients with HIV infection who live in a pre-highly active antiretroviral therapy area. ${ }^{1,2}$ Generally, CMV, herpes simplex virus (HSV), and candida are re-
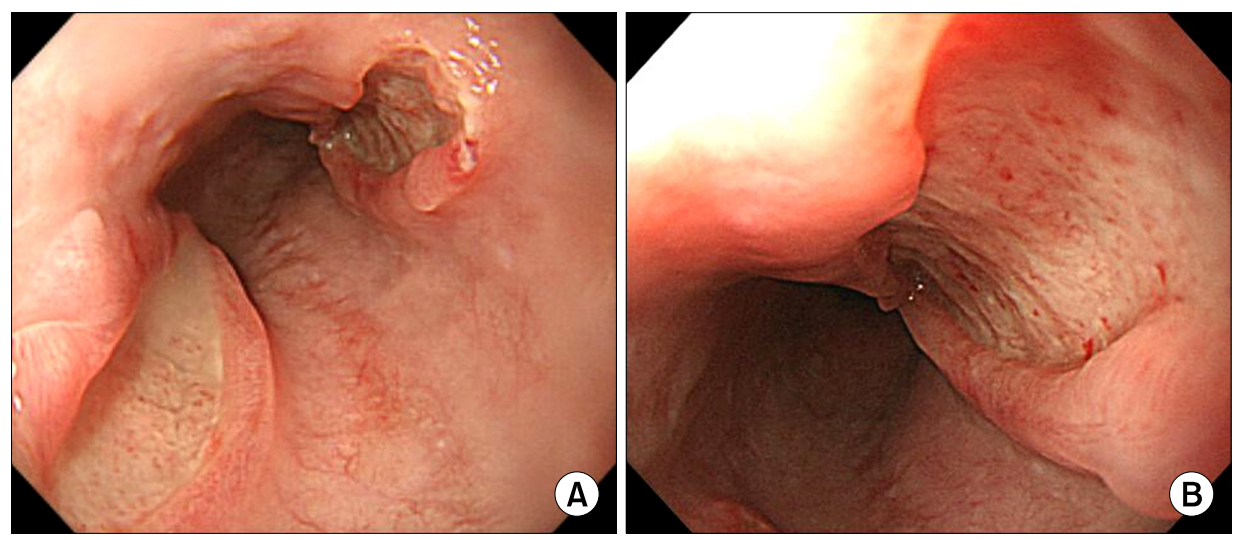

Fig. 1. Endoscopic findings. The upper endoscopy shows two longitudinal, well-demarcated, deep ulcers, about $20 \times 10 \mathrm{~mm}$ and $15 \times 10 \mathrm{~mm}$ in size, in the middle to distal part of the esophagus. (A) General view. (B) Close-up view.

Received: August 15, 2017 Revised: August 28, 2017 Accepted: August 28, 2017

Department of Internal Medicine, Kosin University College of Medicine, 262 Gamcheon-ro, Seo-gu, Busan 49267, Korea Tel: +82-51-990-5061, Fax: +82-51-990-5055, E-mail: parksj6406@daum.net

Copyright $\odot 2017$ Korean College of Helicobacter and Upper Gastrointestinal Research

() The Korean Journal of Helicobacter and Upper Gastrointestinal Research is an Open-Access Journal. All articles are distributed under the terms of the Creative Commons Attribution Non-Commercial License (http://creativecommons.org/licenses/by-nc/4.0) which permits unrestricted non-commercial use, distribution, and reproduction in any medium, provided the original work is properly cited. 

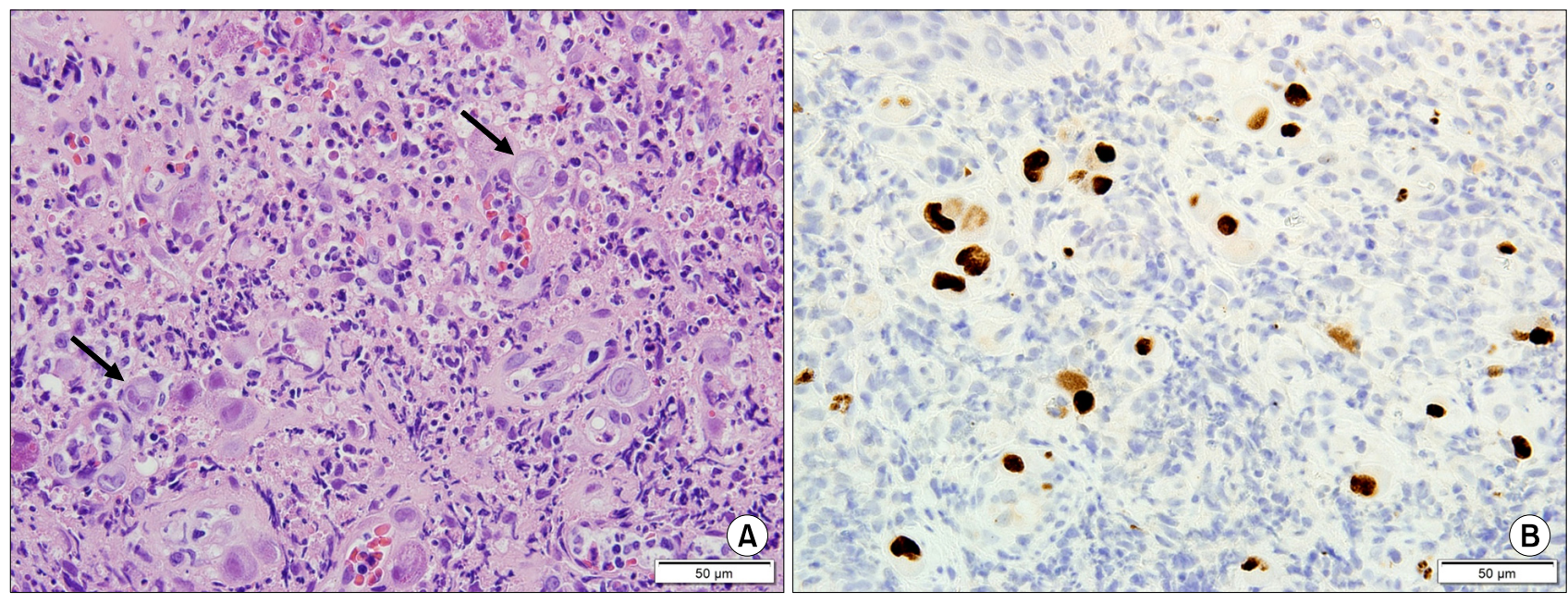

Fig. 2. (A) Histopathologically, endoscopic biopsy shows characteristic "owl's-eye" intranuclear viral inclusions (large amphophilic to basophilic body surrounded by a halo, arrows) within the ulcer base (H\&E, $\times 400)$. (B) Positive immunoreaction with cytomegalovirus is verified in the immunohistochemical staining (immunohistochemical stain, $\times 400$ ).

garded as the main causes of esophageal ulcer in patients with $\mathrm{AIDS}^{3}$ In this case, we identified CMV infection at the giant esophagus ulcers.

There has been no specific agent verified in a subset of AIDS patients with esophageal ulcer in clinical practice. In such cases, this ulcer is denominated as idiopathic esophageal ulcer. ${ }^{1}$ Wilcox et al. ${ }^{1}$ reported that the proportions of idiopathic esophageal ulcers, 40\%; esophageal ulcers with CMV, 45\%; and esophageal ulcers with HSV were 5\% in 100 AIDS patients with esophageal ulcer, respectively. A recent study revealed that HIV infection itself could be related with giant idiopathic esophageal ulcers in AIDS patients. ${ }^{4}$ In terms of endoscopic findings, it is difficult to differentiate esophageal ulcer caused by CMV and idiopathic esophageal ulcer. Therefore, upper endoscopy with biopsy is important to identify the causes of esophageal ulcer and histopathologic analyses including
IHC tests are mandatory.

\section{REFERENCES}

1. Wilcox CM, Schwartz DA, Clark WS. Esophageal ulceration in human immunodeficiency virus infection. Causes, response to therapy, and long-term outcome. Ann Intern Med 1995;123: 143-149.

2. Wilcox CM, Rodgers W, Lazenby A. Prospective comparison of brush cytology, viral culture, and histology for the diagnosis of ulcerative esophagitis in AIDS. Clin Gastroenterol Hepatol 2004;2:564-567.

3. Brunaldi MO, Rezende RE, Garcia SB, Machado AA, Módena JL, Zucoloto S. Esophageal ulcer in Brazilian patients with HIV: prevalence and comparative analysis among diagnostic methods. AIDS Patient Care STDS 2010;24:311-316.

4. Lv B, Cheng X, Gao J, et al. Human immunodeficiency virus (HIV) is highly associated with giant idiopathic esophageal ulcers in acquired immunodeficiency syndrome (AIDS) patients. Am J Transl Res 2016;8:4464-4471. 